Article

\title{
Evaluation for the Removal Efficiency of VOCs and Heavy Metals by Zeolites-Based Materials in the Wastewater: A Case Study in the Tito Scalo Industrial Area
}

\author{
Maura Mancinelli ${ }^{1}\left(\mathbb{D}\right.$, Antonella Arfè ${ }^{1}$, Annalisa Martucci ${ }^{1, *} \mathbb{C}$, Luisa Pasti ${ }^{2}$, Tatiana Chenet ${ }^{2} \mathbb{D}$, \\ Elena Sarti $^{2}$, Giulia Vergine ${ }^{2}$ (D) and Claudia Belviso ${ }^{3, *(D)}$ \\ 1 Department of Physics and Earth Sciences, University of Ferrara, Via Saragat 1, 44122 Ferrara, Italy; \\ maura.mancinelli@unife.it (M.M.); anto.arfe.03@gmail.com (A.A.) \\ 2 Department of Chemical and Pharmaceutical Sciences, University of Ferrara, Via Luigi Borsari 46, \\ 44121 Ferrara, Italy; luisa.pasti@unife.it (L.P.); tatiana.chenet@unife.it (T.C.); elena.sarti@unife.it (E.S.); \\ giulia.vergine@unife.it (G.V.) \\ 3 National Research Council, Institute of Methodologies for Environmental Analysis—CNR, Contrada S. \\ Loja-Zona Industriale C.P. 27, 85050 Tito Scalo, Italy \\ * Correspondence: mrs@unife.it (A.M.); claudia.belviso@imaa.cnr.it (C.B.); Tel.: +39-0532-974730 (A.M.); \\ $+39-0971-427224$ (C.B.)
}

Received: 20 October 2020; Accepted: 20 November 2020; Published: 22 November 2020

\begin{abstract}
The current study was designed to demonstrate the efficiency of selected zeolites in the immobilization of heavy metals and volatile organic compounds from water in the industrial area of Tito Scalo (Basilicata Region in Southern Italy). The efficiency of zeolite materials has been evaluated by analyzing real water samples, by a multi-technique approach. Gas chromatography (GC) and inductively coupled plasma optical emission spectrometry (ICP-OES) were selected for the detection of volatile organic compounds (VOCs) and heavy metals respectively, and then by thermal analysis (TG, DTA) and X-ray powder diffraction (XRD) to verify the presence of contaminants in the structural channels of the adsorbents. ZSM-5 zeolite (MFI topology) was suitable for volatile organic compounds, showing removal efficiencies $>87 \%$. 13X (FAU topology) was more selective for in situ abatements of heavy metals, with efficiencies up to $100 \%$. After VOCs and heavy metals removal, structure refinements of loaded zeolites highlighted variations of both lattice parameters and extraframework content confirming the pollutants immobilization in the framework microporosities. The occurrence of these species was also confirmed by DTA curves showing different phenomena explained on the basis of the nature and number of extraframework species hosted in the zeolite micropores.
\end{abstract}

Keywords: Tito Scalo; groundwater contamination; ZSM-5 and 13X zeolites; heavy metals; VOCs

\section{Introduction}

Contamination of surface and groundwater is considered a global emergency due to the very fast development of industries, the badly conceived urbanization, as well as the agricultural practices. Being frequently a recipient for these contaminants, the aquatic ecosystem is seriously deteriorated and sometimes hopelessly compromised by the occurrence of natural and human-induced chemicals. A wide range of hazardous pollutants is released from nonpoint broadly distributed sources, including bioaccumulative and toxic chemicals (i.e., heavy metals such as lead, mercury, and chromium) and persistent and mobile organic compounds (PMOCs) (i.e., volatile organic compounds (VOCs), methyl-tertbutylether (MTBE), short-chain perfluoroalkyl acids (PFAAs), and tris(2-chloroethyl) 
phosphate (TCEP)) [1-4]. Their presence at trace and ultra-trace levels might cause the development of sub-lethal toxic effects in water and groundwater systems [5] due to the difficulty associated with pollutants removal from water systems, the variety of source sizes and shapes, the pollutants fast mobility, water solubility, and sorption tendency. Spatial and temporal variations in water chemistry are mandatory to protect and enhance the status of aquatic ecosystems, as well as to bring applicable solutions to the subject.

In the present work, we undertook a study of the industrial area of Tito Scalo which is designated as "Siti di Interesse Nazionale (SIN)" (contaminated Sites of National Interest) and, according to Italian law, its management is entrusted to the national authorities [6]. This contaminated site is characterized by the presence of groundwater containing chlorinated solvents (trichlorethylene, 1,2-dichloroethylene, 1,1-dichloroethylene, and vinyl chloride), metals (As, Fe, and $\mathrm{Mn}$ ), and sulfates in concentrations above the reference threshold (CSC). In order to control both heavy metals and VOCs in this site, we have selected zeolites with different silicon vs. aluminum molar ratio (SAR) as a function of pollutants composition and nature. Zeolites represent a benchmark in the area of porous materials, due to their efficiency as ion exchanger (i.e., heavy-ion removal) and organic adsorbent media. The three-dimensional networks containing well-defined channels and cavities imparts high porosity and a large surface area to these materials whose selectivity and activity towards guest pollutant species can be modulated by acting on their structure and chemical features. Additionally, rapid sorption kinetics, no salt and humic substances interference, high stability in water during prolonged periods of time and against aggressive chemicals make them a viable alternative to other reactive media. The ability of zeolites with a low $\mathrm{Si} / \mathrm{Al}$ ratio to remove heavy metal ions, such as $\mathrm{Cd}^{2+}, \mathrm{Pb}^{2+}, \mathrm{Ni}^{2+}$, $\mathrm{Cu}^{2+}$, and $\mathrm{Zn}^{2+}$ by ionic exchange has been largely demonstrated to produce drinking water [7-11]. Besides, zeolites characterized by SAR values higher than $5 \mathrm{~mol} / \mathrm{mol}$ are more hydrophobic materials which are widely used in adsorption-related applications [12-16].

This study, investigated at pilot scale and under real environmental conditions, provides a rapid and low-cost solution for the decontamination of the Tito Scalo polluted streams by the identification of efficient selective adsorbent media able to immobilize the contaminating species. In particular, ZSM-5 zeolite (MFI topology) turned out to be suitable for chlorinated solvent molecules, while 13X (FAU topology) was more selective for in situ abatements of heavy metals. The efficiency of zeolite materials has been evaluated during the water treatment by analyzing real water samples, by gas chromatography (GC) and inductively coupled plasma optical emission spectrometry (ICP-OES) for VOCs and heavy metals respectively, and then verifying the presence of contaminants in the structural channels of the adsorbents by thermal analysis (TG, DTA) and X-ray powder diffraction (XRD).

\section{Materials and Methods}

\subsection{Sampling}

The SIN is located about $4 \mathrm{~km}$ from the village of Tito (Basilicata, Italy) (Figure 1) within an area characterized by intense industrial activities. The samples of polluted groundwater were collected in piezometric wells located in three different areas inside the SIN (Figure 1). Before the sampling activity, each piezometric well was purged. The low-flow sampling of groundwater was carried out in dynamic mode by means of an electro-submersible pump. The samples were collected using $1 \mathrm{~L}$ glass bottles with pressure caps ensuring that there was no gap between the sample and the cap. The samples were fixed using hydrochloric acid and stored in a refrigerator at $4{ }^{\circ} \mathrm{C}$ until the analysis. $50 \mathrm{~mL}$ of groundwater was collected in plastic bottles for metals determination. The samples were analyzed within ten days after collection. References about thermodynamic studies pertaining to selected VOCs (e.g., t-amyl methyl ether, ethyl t-butyl ether, di-isopropyl ether, $n$-hexane, fluorobenzene) are available in the literature [17-27]. 

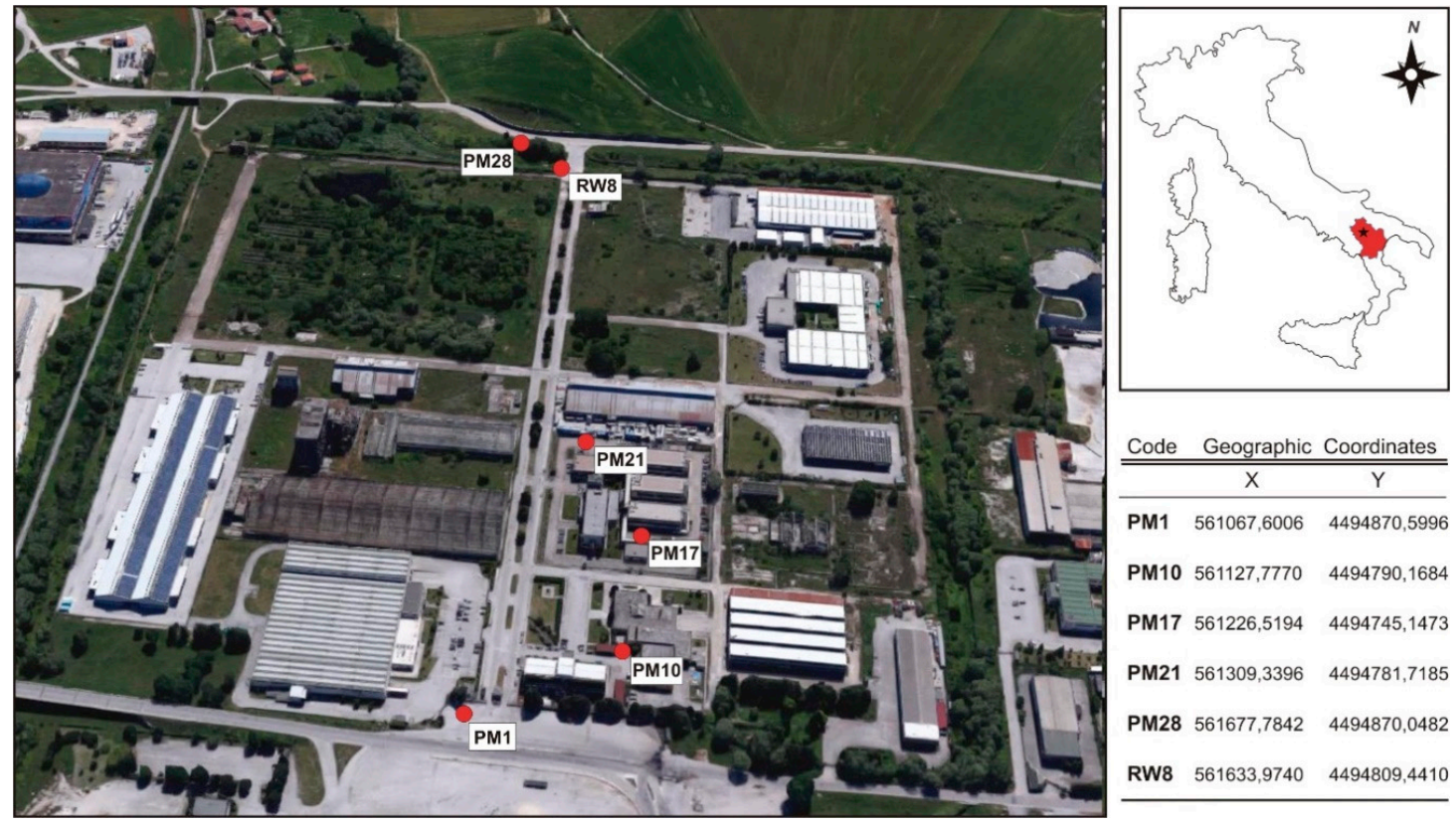

Figure 1. View of the study area with the sampling points and geographic coordinates.

\subsection{Materials}

High-silica ZSM-5 (280 $\mathrm{SiO}_{2} / \mathrm{Al}_{2} \mathrm{O}_{3}$ molar ratio, 0.05 wt $\% \mathrm{Na}_{2} \mathrm{O}$ and 0.1 wt \% $\mathrm{NH}_{4}$ content) and $13 \mathrm{X}\left(1.27 \mathrm{SiO}_{2} / \mathrm{Al}_{2} \mathrm{O}_{3}\right.$ molar ratio, $\left.16.28 \mathrm{wt} \% \mathrm{Na}_{2} \mathrm{O}\right)$ zeolites were supplied as powders in their as-synthetized form by Zeolyst International (Conshohocken, PA, USA) and Honeywell UOP (Des Plaines, IL, USA) respectively. More details about the selected adsorbent media are reported in Table 1 and $[28,29]$.

Table 1. Structural and physico-chemical characteristics of zeolites under investigation.

Selected Zeolites
13X: $\mathrm{Na} 90.04\left[\mathrm{Al}_{92.64} \mathrm{Si} 99.78 \mathrm{O}_{384}\right] \bullet 200.03 \mathrm{H}_{2} \mathrm{O}$
Cation type: $\mathrm{Na}$
$\mathrm{Si} / \mathrm{Al}(\mathrm{mol} / \mathrm{mol}): 1.08$
Channel dimensionality: Topological (pore opening
6-ring): 3-dimensional
$\mathrm{SSA}_{\mathrm{BET}}\left(\mathrm{m}^{2} \mathrm{~g}^{-1}\right): 791 ; \mathrm{SSA}_{\text {microp }}\left(\mathrm{m}^{2} \mathrm{~g}^{-1}\right): 731 ;$
$\mathrm{V}_{\mathrm{p}}\left(\mathrm{cm}^{3} \mathrm{~g}^{-1}\right): 0.301 ; \mathrm{V}_{\text {microp }}\left(\mathrm{cm}^{3} \mathrm{~g}^{-1}\right): 0.267$

ZSM-5: [Sig6 $\left.\mathrm{O}_{192}\right]$

Cation type: $\mathrm{NH}_{4}$

$\mathrm{Si} / \mathrm{Al}(\mathrm{mol} / \mathrm{mol}):>500$

Channel dimensionality: Topological (pore opening $>$

6-ring): 3-dimensional

$\operatorname{SSA}_{\mathrm{BET}}\left(\mathrm{m}^{2} \mathrm{~g}^{-1}\right)$ : 550; $\mathrm{SSA}_{\text {microp }}\left(\mathrm{m}^{2} \mathrm{~g}^{-1}\right)$ : 355;

$\mathrm{V}_{\mathrm{p}}\left(\mathrm{cm}^{3} \mathrm{~g}^{-1}\right): 0.52 ; \mathrm{V}_{\text {microp }}\left(\mathrm{cm}^{3} \mathrm{~g}^{-1}\right): 0.09$

[MFI]

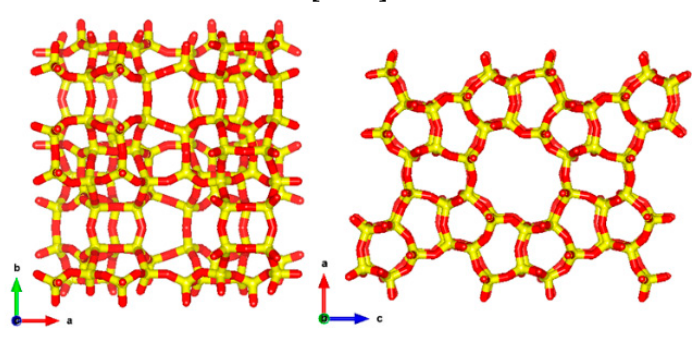




\subsection{Adsorption Experiments}

The adsorption of the contaminants was investigated using the batch method. Adsorption experiments were carried out in $20 \mathrm{~mL}$ crimp top reaction glass flasks sealed with PTFE septa (Supelco, PA, USA). In the case of VOCs adsorption experiments, the flasks were filled in order to have the minimum headspace. For VOCs, a solid/solution ratio of 4:1 $\left(\mathrm{mg} \mathrm{mL}^{-1}\right)$ was employed, whereas for heavy metals the solid/solution ratio was $1: 1\left(\mathrm{mg} \mathrm{mL}^{-1}\right)$. After $24 \mathrm{~h}$ equilibration at a temperature of $25.2 \pm 0.5^{\circ} \mathrm{C}$ under stirring, the zeolites were separated from the solution by filtration using $25 \mathrm{~mm}$ syringe filters with PVDF membrane $0.45 \mu \mathrm{m}$ (Agilent Technologies, Santa Clara, CA, USA). The initial concentrations $\left(C_{0}\right)$ and the concentrations at equilibrium $\left(C_{e}\right)$ of the contaminants in the water samples were determined (by ICP-OES for metals and HS-GC-MS for VOCs) and the adsorbed quantities were calculated with the following equation:

$$
q=\frac{\left(C_{0}-C_{e}\right) \cdot V}{m}
$$

where $q\left(\mathrm{mg} \mathrm{g}^{-1}\right)$ is the contaminant uptake $\left(\mathrm{mg} \mathrm{g}^{-1}\right), C_{0}$ is the initial contaminant concentration in the solution $\left(\mathrm{mg} \mathrm{L}^{-1}\right), C_{e}$ the contaminant concentration in the solution at equilibrium $\left(\mathrm{mg} \mathrm{L}^{-1}\right)$, $V$ is the solution volume (L) and $m$ is the mass of adsorbent (g). In the present work, the adsorption isotherm was not estimated, since the real samples contained a variety of different compounds that could be characterized by different adsorption properties. In addition, competitive phenomena could also modify the single-component adsorption. Therefore, to investigate the capability of zeolite in the removal of a complex mixture of contaminants, we evaluated the adsorbed quantity with respect to the total VOC concentration (see Section 2.5). For the adsorption of VOCs onto zeolites, different isotherm models have been employed [30-36].

\subsection{Inductively Coupled Plasma Optical Emission Spectrometry}

The concentration of As, Fe, and Mn in the water samples, before and after the contact with zeolite 13X, was determined by ICP-OES (Perkin-Elmer Optima 3100 XL, Inc. 940 Winter Street Waltham, MA 02451 USA) (axial view) equipped with a solid-state charge-coupled device detector (CCD), a peristaltic pump and a low-flow GemCone nebulizer coupled to a cyclonic spray chamber. Analytical lines $188.98 \mathrm{~nm}, 259.94 \mathrm{~nm}$, and $293.30 \mathrm{~nm}$ were selected for the quantitative determination of As, $\mathrm{Fe}$, and $\mathrm{Mn}$ respectively. The ICP-OES measuring parameters were: plasma flow $=15 \mathrm{~L} \mathrm{~min}^{-1}$, auxiliary flow $=0.5 \mathrm{~L} \mathrm{~min}^{-1}$, nebuliser flow $=0.65 \mathrm{~L} \mathrm{~min}^{-1}, \mathrm{RF}$ power $=1350 \mathrm{~W}$.

\subsection{Gas Chromatography}

The concentration of VOCs in the aqueous solution before and after the contact with zeolite ZSM-5 was determined by Headspace Gas Chromatography coupled to Mass Spectrometry (HS-GC-MS). The analyses were carried out with an Agilent GC-MS system (Santa Clara, CA, USA) consisting of a GC 6850 Series II Network coupled to a Pal G6500-CTC injector and a Mass Selective Detector 5973 Network.

HS autosampler injector conditions were: incubation oven temperature $85^{\circ} \mathrm{C}$, incubation time $50 \mathrm{~min}$, headspace syringe temperature $90^{\circ} \mathrm{C}$, agitation speed $250 \mathrm{rpm}$, agitation on time $30 \mathrm{~s}$, agitation off time $5 \mathrm{~s}$, injection volume $1 \mathrm{~mL}$, fill speed $30 \mu \mathrm{L} \mathrm{s}^{-1}$, syringe pull-up delay $5 \mathrm{~s}$, injection speed $250 \mu \mathrm{L} \mathrm{s}^{-1}$, pre-injection delay $0 \mathrm{~s}$, post-injection delay $2 \mathrm{~s}$, syringe flush $30 \mathrm{~s}$ with nitrogen.

The injected solutions consisted of $10 \mathrm{~mL}$ of sample solutions containing $1.8 \mathrm{~g}$ of $\mathrm{NaCl}$ and $10 \mu \mathrm{L}$ of $500 \mathrm{mg} \mathrm{L}^{-1}$ of fluorobenzene in methanol as an internal standard. An HP-VOC GC column $(\mathrm{L}=30 \mathrm{~m}$, I.D. $=0.2 \mathrm{~mm}, \mathrm{df}=1.12 \mu \mathrm{m}$ film thickness, Agilent, Santa Clara, CA, USA) was used. The carrier gas was high purity helium with a constant flow rate of $1.0 \mathrm{~mL} \mathrm{~min}^{-1}$. The oven temperature gradient started at $35^{\circ} \mathrm{C}$ for $5 \mathrm{~min}$, then ramped to $70{ }^{\circ} \mathrm{C}$ at $5{ }^{\circ} \mathrm{C} \mathrm{min}^{-1}$ with a hold time of $0 \mathrm{~min}$, finally it ramped $230^{\circ} \mathrm{C}$ at $20^{\circ} \mathrm{C} \mathrm{min}^{-1}$ with a hold time of $1 \mathrm{~min}$. All samples were injected in split mode (10:1). 
The mass spectrometer operated in electron impact mode (positive ion, $70 \mathrm{eV}$ ). The source temperature and the quadrupole temperature were set to $230^{\circ} \mathrm{C}$ and $150{ }^{\circ} \mathrm{C}$ respectively. The mass spectra were acquired in full scan mode. The electronic scan speed was $1562 \mathrm{amu} \mathrm{s}^{-1}$ in a mass range from 30 to $300 \mathrm{amu}$. For identification and quantification of the target analytes, the SIM (selected ion monitoring) chromatograms were extracted from the acquired signal by selecting the most abundant characteristic fragments at $m / z=41,43,57$ ( $n$-hexane and decane), $m / z=41,42,43$ (2-methylpentane), $m / z=41,57$, 73 (methyl t-butyl ether, MTBE), $m / z=43,45,87$ (diisopropyl ether, DIPE), $m / z=43,55,73$ (t-amyl methyl ether, TAME), $m / z=57,59,87$ (ethyl t-butyl ether, ETBE), and $m / z=50,70,96$ (fluorobenzene). Chromatographic peaks of analytes were identified by comparison of the retention time and the mass spectrum with standard compounds and library data.

The total VOCs concentration in each sample was determined according to the procedure proposed by the Italian Institute for Environmental Protection and Research (ISPRA) [37] by considering the area of the chromatographic peaks in a specific retention window, from 4.6 to $17.2 \mathrm{~min}$ which was the retention times for 2-methylpentane and decane respectively. The sum of the areas of the peaks within the selected retention window was expressed as a concentration of $n$-hexane through external calibration to represent the total VOC concentration. The areas of the peaks of ethers (MTBE, ETBE, TAME, and DIPE) were subtracted from the total, if present.

\subsection{Quality Assurance}

The limit of detection (LOD) for the analytes (VOCs, As, Fe and Mn), calculated from the blank value plus three times the standard deviation of the 10 replicates of blank solutions [38], were $58.94 \mu \mathrm{g} \mathrm{L}^{-1}$ for As, $1.36 \mu \mathrm{g} \mathrm{L}^{-1}$ for Fe, $2.58 \mu \mathrm{g} \mathrm{L}^{-1}$ for Mn, and $0.17 \mathrm{mg} \mathrm{L}^{-1}$ for VOCs.

The procedural quality control for the analysis of the metals was verified with recovery experiments by adding a known quantity of a standard solution containing the three metals. The recovery obtained was $92 \pm 11 \%$ for As, $98 \pm 5 \%$ for Fe, and $96 \pm 9 \%$ for Mn. For VOCs, quality control was carried out by determining the recovery of fluorobenzene which was added to each sample before analysis; the recovery obtained was $103 \pm 13.6 \%$.

Reagent blanks were analyzed to account for possible contamination during sample preparation; the reagent blanks were subtracted from the value of the concentration of the target analytes present in the samples.

\subsection{Thermal Analyses}

Thermogravimetric (TG) and differential thermal analysis (DTA) measurements of both loaded and bare zeolite samples were performed in constant air flux conditions using an STA 409 PC LUXX ${ }^{\circledR}$ —Netzch (Gerätebau, Germany) operating at $10^{\circ} \mathrm{C} / \mathrm{min}$ heating rate, from room temperature (RT) to $900^{\circ} \mathrm{C}$. The tests were conducted using sample amounts of approximately $65 \mathrm{mg}$.

\subsection{X-ray Powder Diffraction Data Collection and Refinement Strategy}

X-ray diffraction patterns on powders of ZSM- 5 and 13X zeolites before and after contact with the waters of the reference wells were carried out on a Bruker D8 Advance diffractometer $(\mathrm{Cu} K \alpha 1,2$ radiation) equipped with a Sol-X detector. Diffraction data were collected at $R T$, in $10-120^{\circ} 2 \theta$ ranges, with a counting time of $20 \mathrm{~s}$ each $0.02^{\circ} 2 \theta$. The structural refinements were run through a full profile Rietveld analysis using the GSAS [39] software and the EXPGUI graphical interface [40]. Unit-cell and structural parameters were determined starting from the monoclinic $P 2_{1} / n$ (for ZSM-5) and the cubic $F d-3 m$ (for 13X) space groups, respectively. The Bragg peak profiles were modeled by a Pseudo-Voigt function (Thompson-Cox-Hastings) with the peak cut-off set to $0.001 \%$ of the peak maximum by means of three Gaussian terms (i.e., GU, GV, and GW, respectively), and the two Lorentzian broadening coefficients (i.e., LX, and LY, respectively) plus an asymmetry contribution. The $2 \theta$ zero shift, scale factor, and unit-cell parameters were refined. The instrumental background was empirically fitted using a Chebyshev polynomial of the first type with 18 (ZSM-5) and 20 (13X) variable coefficients data 
set. Soft restraints were initially imposed on tetrahedral bond distances $(1.625 \AA$, tolerance $(\sigma)$ value of $0.04 \AA$ ) and then completely removed in the final cycles. Finally, atomic coordinates, site occupancy, and isotropic atomic displacement parameters were refined. Tables 2 and 3 report the details of the data collections and Rietveld refinements. The crystal size determination was achieved by the integral breadth based calculation of volume-weighted mean crystallize sizes assuming intermediate crystallite size broadening modeled by a Voigt function.

Table 2. Details of the data collection and Rietveld refinements of 13X before and after metals adsorption.

\begin{tabular}{cccccccc}
\hline & $\mathbf{1 3 X}$ & PM1 & PM10 & PM17 & PM21 & PM28 & RW8 \\
\hline Space group & $F d-3 m$ & $F d-3 m$ & $F d-3 m$ & $F d-3 m$ & $F d-3 m$ & $F d-3 m$ & $F d-3 m$ \\
$a=b=c(\AA)$ & $24.9859(3)$ & $24.8980(3)$ & $24.8762(2)$ & $24.9160(3)$ & $24.9067(2)$ & $24.8780(3)$ & $24.8773(3)$ \\
$\alpha=\beta=\gamma\left({ }^{\circ}\right)$ & 90 & 90 & 90 & 90 & 90 & 90 & 90 \\
$V\left(\AA^{3}\right)$ & $15,598.70(3)$ & $15,434.52(3)$ & $15,394.00(7)$ & $15,467.9(3)$ & $15,450.68(2)$ & $15,397.39(3)$ & $15,396.00(6)$ \\
Wavelength $(\AA)$ : $\mathrm{Cu} \mathrm{K} \alpha_{1}$ & 1.540593 & 1.540593 & 1.540593 & 1.540593 & 1.540593 & 1.540593 & 1.540593 \\
$\mathrm{Cu} \mathrm{K} \alpha_{2}$ & 1.544427 & 1.544427 & 1.544427 & 1.544427 & 1.544427 & 1.544427 & 1.544427 \\
Refined $2 \theta\left(^{\circ}\right)$ range & $10-120^{\circ}$ & $10-120^{\circ}$ & $10-120^{\circ}$ & $10-120^{\circ}$ & $10-120^{\circ}$ & $10-120^{\circ}$ & $10-120^{\circ}$ \\
\hline
\end{tabular}

Table 3. Details of the data collection and Rietveld refinements of ZSM-5 before and after VOCs adsorption.

\begin{tabular}{cccccccc}
\hline & ZSM-5 & PM1 & PM10 & PM17 & PM21 & PM28 & RW8 \\
\hline Space group & $P 2_{1} / n$ & $P 2_{1} / n$ & $P 2_{1} / n$ & $P 2_{1} / n$ & $P 2_{1} / n$ & $P 2_{1} / n$ & $P 2_{1} / n$ \\
$a(\AA)$ & $19.8999(5)$ & $19.9018(4)$ & $19.8936(4)$ & $19.8879(9)$ & $19.8934(6)$ & $19.8946(5)$ & $19.8968(5)$ \\
$b(\AA)$ & $20.1174(6)$ & $20.1256(4)$ & $20.1166(4)$ & $20.1107(7)$ & $20.1152(4)$ & $20.1176(4)$ & $20.1216(8)$ \\
$c(\AA)$ & $13.3892(4)$ & $13.3877(3)$ & $13.3817(3)$ & $13.3834(4)$ & $13.3834(4)$ & $13.3840(4)$ & $13.3834(8)$ \\
$\alpha\left(^{\circ}\right)$ & 90 & 90 & 90 & 90 & 90 & 90 & 90 \\
$\beta\left(^{\circ}\right)$ & $90.546(3)$ & $90.558(2)$ & $90.567(2)$ & $90.550(4)$ & $90.555(4)$ & $90.557(5)$ & $90.557(5)$ \\
$\gamma\left({ }^{\circ}\right)$ & 90 & 90 & 90 & 90 & 90 & 90 & 90 \\
$V\left(\AA^{3}\right)$ & $5359.90(3)$ & $5362.00(2)$ & $5355.00(2)$ & $5352.60(4)$ & $5355.23(3)$ & $5356.42(2)$ & $5357.80(1$ \\
Cu K $\alpha_{2}$ & 1.540593 & 1.540593 & 1.540593 & 1.540593 & 1.540593 & 1.540593 & 1.540593 \\
Wavelength $(\AA)$ Cu K $\alpha_{1}$ & 1.544427 & 1.544427 & 1.544427 & 1.544427 & 1.544427 & 1.544427 & 1.544427 \\
Refined $2 \theta\left(^{\circ}\right)$ range & $10^{\circ}-120^{\circ}$ & $10^{\circ}-120^{\circ}$ & $10^{\circ}-120^{\circ}$ & $10^{\circ}-120^{\circ}$ & $10^{\circ}-120^{\circ}$ & $10^{\circ}-120^{\circ}$ & $10^{\circ}-120^{\circ}$ \\
\hline
\end{tabular}

\section{Results and Discussion}

\subsection{Adsorption}

The total VOCs concentration in each sample is reported in the second column $\left(C_{0}\right)$ of Table 4 . Table 4 also reports the contaminants uptake $(q)$ and removal efficiency obtained by using zeolite ZSM- 5 as adsorbent material. Analogously, Table 4 shows the initial contaminants concentration $\left(C_{0}\right)$, contaminants uptake $(q)$, and removal efficiency obtained from adsorption on zeolite 13X for Fe and Mn metal ions.

Volatile organic compounds, and among them chlorinated substances, are commonly found in groundwaters due to their vast use as solvents [41]. VOCs were present in all the samples analyzed in a concentration range from 0.75 to $163 \mathrm{mg} \mathrm{L}^{-1}$, with an important contribution of 1,2-dichloroethylene and trichloroethylene which were identified in all the samples. Zeolite ZSM- 5 has been selected in this work due to its high uptake towards VOCs [42-48]; in fact, it showed high removal efficiencies (>87\%) for this class of contaminants present in the groundwater samples from Tito Scalo, with the adsorbed quantity $(q)$ increasing with the increase of initial contaminant concentration in the water sample.

For concerned metals, As was absent in all the water samples, Mn was detected in all samples except one (PM28) in a concentration range between 400 and $1750 \mu \mathrm{g} \mathrm{L}^{-1}$. Fe also was present in all samples except one (PM1), but in lower concentrations compared to Mn, from about 1.5 to $57 \mu \mathrm{g} \mathrm{L}^{-1}$. In groundwaters, under an anaerobic environment. their presence can be caused by reducing conditions that promote the stability of Fe and $\mathrm{Mn}$ as soluble divalent ions [49]. For both metals, zeolite 13X proved to be an efficient adsorbent, with efficiencies up to $100 \%$. Lower removal efficiencies ( $53 \%$ and $68 \%$ for Fe and Mn respectively) were obtained only for those samples showing a higher initial metal 
content, this decrease in the removal efficiency may be due to the saturation of the adsorbent material towards these metals.

Table 4. Initial contaminants concentration $\left(C_{0}\right)$, contaminants uptake $(q)$, and removal efficiency, with standard deviations for VOCs adsorption on zeolite ZSM-5 and for Fe and Mn on zeolite 13X.

\begin{tabular}{|c|c|c|c|}
\hline \multicolumn{4}{|c|}{ VOCs } \\
\hline Sample & $C_{0}\left(\mathrm{mg} \mathrm{L}^{-1}\right)$ & $q\left(\mathrm{mg} \mathrm{g}^{-1}\right)$ & Removal Efficiency (\%) \\
\hline PM1 & $164 \pm 12.63$ & $37 \pm 1.30$ & 99.65 \\
\hline PM10 & $2.6 \pm 0.26$ & $0.6 \pm 0.20$ & 96.89 \\
\hline PM17 & $20 \pm 1.77$ & $4.3 \pm 0.51$ & 98.54 \\
\hline PM21 & $5.5 \pm 0.95$ & $1.2 \pm 0.45$ & 97.58 \\
\hline PM28 & $0.75 \pm 0.09$ & $0.2 \pm 0.11$ & 87.31 \\
\hline RW8 & $3.4 \pm 0.28$ & $0.8 \pm 0.21$ & 96.79 \\
\hline \multicolumn{4}{|c|}{$\mathrm{Fe}$} \\
\hline Sample & $C_{0}\left(\mu \mathrm{g} \mathrm{L}^{-1}\right)$ & $q\left(\mu \mathrm{g} \mathrm{g}^{-1}\right)$ & Removal Efficiency (\%) \\
\hline PM1 & - & - & - \\
\hline PM10 & $56.8 \pm 0.56$ & $29.4 \pm 0.47$ & 53.27 \\
\hline PM17 & $2.8 \pm 0.24$ & $2.8 \pm 0.35$ & 100 \\
\hline PM21 & $1.5 \pm 0.11$ & $1.5 \pm 0.31$ & 100 \\
\hline PM28 & $4.9 \pm 0.18$ & $4.8 \pm 0.35$ & 100 \\
\hline RW8 & $6.6 \pm 0.58$ & $6.5 \pm 0.38$ & 100 \\
\hline \multicolumn{4}{|c|}{ Mn } \\
\hline Sample & $C_{0}\left(\mu \mathrm{g} \mathrm{L}^{-1}\right)$ & $q\left(\mu \mathrm{g} \mathrm{g}^{-1}\right)$ & Removal Efficiency (\%) \\
\hline PM1 & $962 \pm 5.2$ & $694 \pm 1.91$ & 73.00 \\
\hline PM10 & $1104 \pm 7.2$ & $1014 \pm 3.80$ & 94.35 \\
\hline PM17 & $578.5 \pm 0.90$ & $554 \pm 1.26$ & 98.40 \\
\hline PM21 & $414 \pm 1.00$ & $412 \pm 1.23$ & 99.83 \\
\hline PM28 & - & - & - \\
\hline RW8 & $1745 \pm 4.3$ & $1172 \pm 3.97$ & 67.99 \\
\hline
\end{tabular}

\subsection{Structural and Thermal Characterization}

Structural and thermal characterization of the adsorbents at the end of the adsorption test confirmed the incorporation of heavy metals and $\mathrm{VOC}_{S}$ inside the microporosities of selected zeolites. A careful examination of both positions and intensities of the $\mathrm{X}$-ray diffraction peaks showed strong differences with respect to those of the as-synthetized materials, especially at low $2 \theta$ angles. Figure 2 compares the XRD patterns of the fresh zeolites with those of the samples after their permanence in polluted groundwater collected in piezometric wells located in different areas inside the SIN.

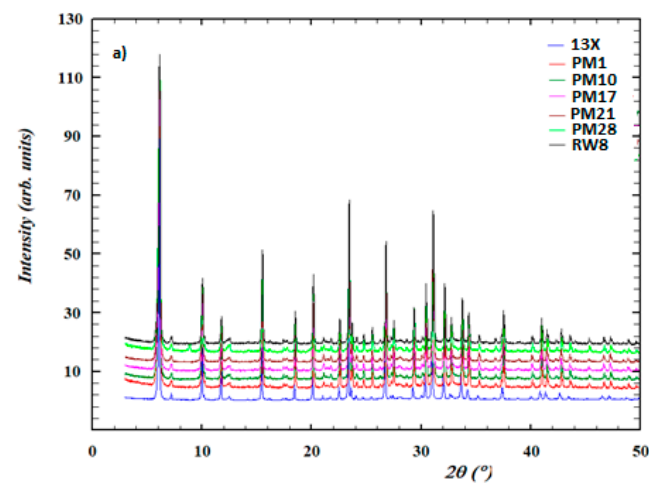

(a)

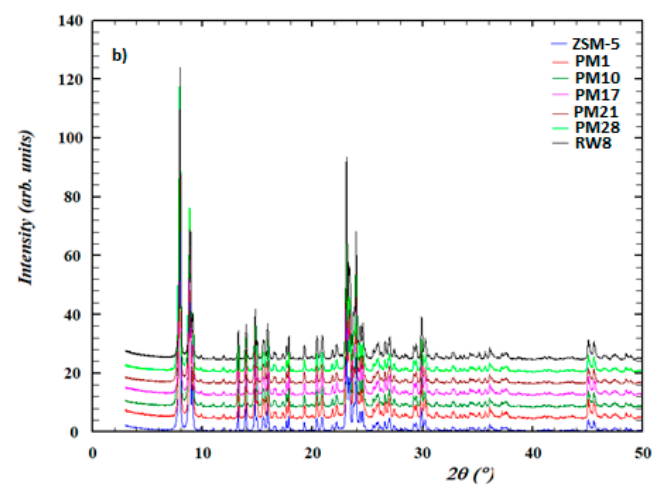

(b)

Figure 2. X-ray powders diffraction patterns of $13 \mathrm{X}(\mathbf{a})$ and ZSM-5 (b) zeolites after adsorption of water from different areas inside the SIN. 
In $13 \mathrm{X}$, the cubic $\mathrm{Fd}-3 m$ symmetry was maintained but the refined lattice parameters and unit-cell volume (V) was remarkably decreased (Table 2). A sensible variation of diffraction profile width was noticed in loaded samples, confirmed by the full width at half maximum (FWHM) values as a function of 2 theta $\left({ }^{\circ}\right)$ as reported in Figure 3 a.

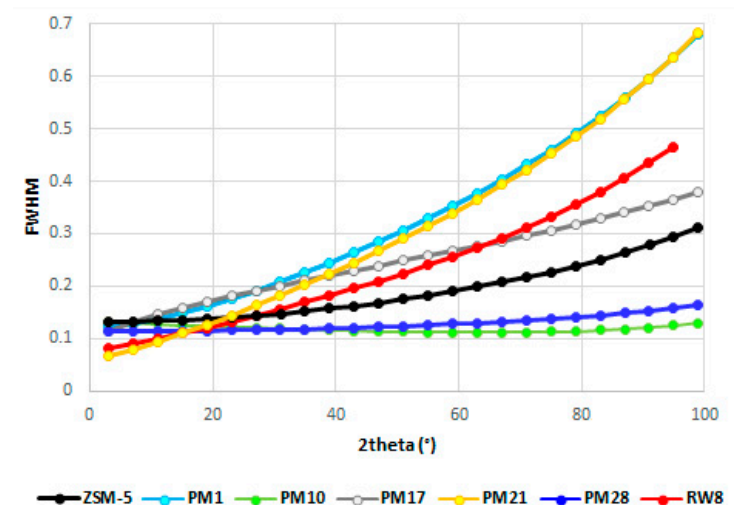

(a)

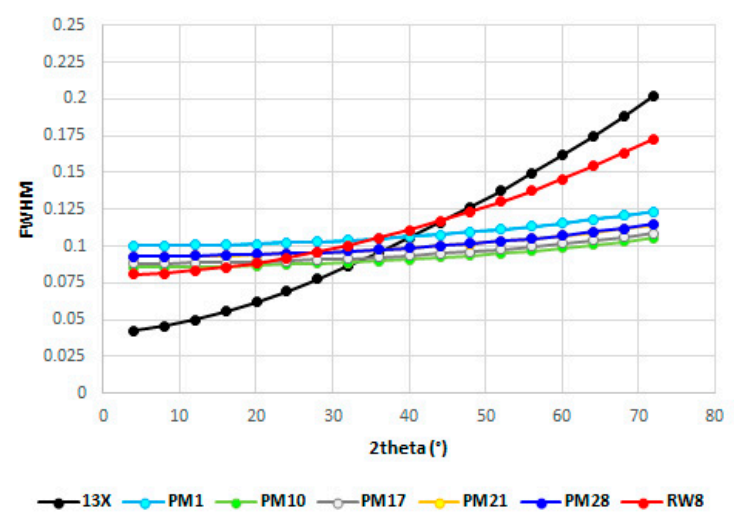

(b)

Figure 3. FWHM values as a function of 2 theta $\left({ }^{\circ}\right)$ of ZSM-5 (a) and $13 \mathrm{X}(\mathbf{b})$.

The average grain sizes of the $13 X$ samples decreased from $120 \AA$ in the fresh sample to about $500 \AA$. No noticeable distortion of the framework was highlighted and the channel's geometry remained about circular as attested by ellipticity, $\varepsilon(\varepsilon=$ largest/shortest oxygen-oxygen bond distances), and the Crystallographic Free Area, CFA (calculated assuming an oxygen ionic radius of $1.35 \AA$ ), parameters, reported in Table 5.

Table 5. Crystallographic Free Area (CFA) and channel ellipticity $(\varepsilon)$ for ZSM-5 and 13X before and after adsorption.

\begin{tabular}{llllllll}
\hline & 13X & PM1 & PM10 & PM17 & PM21 & PM28 & RW8 \\
\hline CFA $\left(\AA^{2}\right)$ & 43.29 & 43.23 & 43.43 & 43.45 & 43.76 & 43.28 & 47.29 \\
$\varepsilon$ & 1.01 & 1.01 & 1.01 & 1.01 & 1.01 & 1.00 & 1.04 \\
Straight channel (SC) [010] Ring A & ZSM-5 & PM1 & PM10 & PM17 & PM21 & PM28 & RW8 \\
CFA $\left(\AA^{2}\right)$ & 22.69 & 21.05 & 23.67 & 24.31 & 23.82 & 23.83 & 24.03 \\
$\varepsilon$ & 1.03 & 1.08 & 1.06 & 1.11 & 1.05 & 1.05 & 1.09 \\
Straight channel (SC) [010] Ring B & ZSM-5 & PM1 & PM10 & PM17 & PM21 & PM28 & RW8 \\
CFA $\left(\AA^{2}\right)$ & 23.03 & 22.42 & 23.08 & 23.50 & 23.01 & 23.01 & 23.61 \\
$\varepsilon$ & 1.02 & 1.08 & 1.03 & 1.10 & 1.04 & 1.04 & 1.06 \\
Sinusoidal or zigzag channel (ZZ) [100] Ring A & ZSM-5 & PM1 & PM10 & PM17 & PM21 & PM28 & RW8 \\
CFA $\left(\AA^{2}\right)$ & 21.65 & 21.59 & 23.54 & 23.98 & 23.63 & 23.63 & 24.07 \\
$\varepsilon$ & 1.05 & 1.08 & 1.08 & 1.12 & 1.08 & 1.08 & 1.06 \\
Sinusoidal or zigzag channel (ZZ) [100] Ring B & ZSM-5 & PM1 & PM10 & PM17 & PM21 & PM28 & RW8 \\
CFA $\left(\AA^{2}\right)$ & 22.65 & 21.49 & 22.70 & 24.27 & 22.87 & 22.87 & 23.05 \\
$\varepsilon$ & 1.06 & 1.12 & 1.09 & 1.10 & 1.10 & 1.10 & 1.11 \\
\hline
\end{tabular}

After heavy metal-exchange, similar wt $\%$ losses during TG analysis (25-29 wt \%) were observed in the 13X sample: $\sim 3 \mathrm{wt} \%$ losses in the $25-100{ }^{\circ} \mathrm{C}$ range due to physically adsorbed water, $22 \sim 26 \mathrm{wt} \%$ losses in the 100-900 ${ }^{\circ} \mathrm{C}$ range [8]. These differences can be explained on the basis of the nature and number of metal exchangeable cations hosted in the zeolite micropores (being Si/Al ratio constant) and, consequently, to the nominal charge $(\mathrm{Z})$ and radius $(\mathrm{r})$ of the charge-compensating cations. These two latter factors are normally combined in the ratio $\mathrm{Z} / \mathrm{r}$ which gives a measure of the ionic potential of exchangeable extraframework (EF) cations.

The DTA curves showed different phenomena occurring with respect to the unloaded samples (Figure 4). The broad exothermic and not well-defined signal observed above $200{ }^{\circ} \mathrm{C}$, with a maximum at $\sim 500{ }^{\circ} \mathrm{C}$, has been usually related to the loss of the hydroxyl groups that compose the zeolite structure. At higher temperature, another exothermic peak was taken as a reference of zeolites thermal 
stability and was attributed to the collapse of the zeolite structure and/or to the recrystallization into a new phase [50-53]. These results suggested that the $13 \mathrm{X}$ thermal stability increases with increasing ionic radii of the ions in the channel-void system and, consequently, the framework distortion by electrostatic interactions, decreases with the increase in ionic radius.
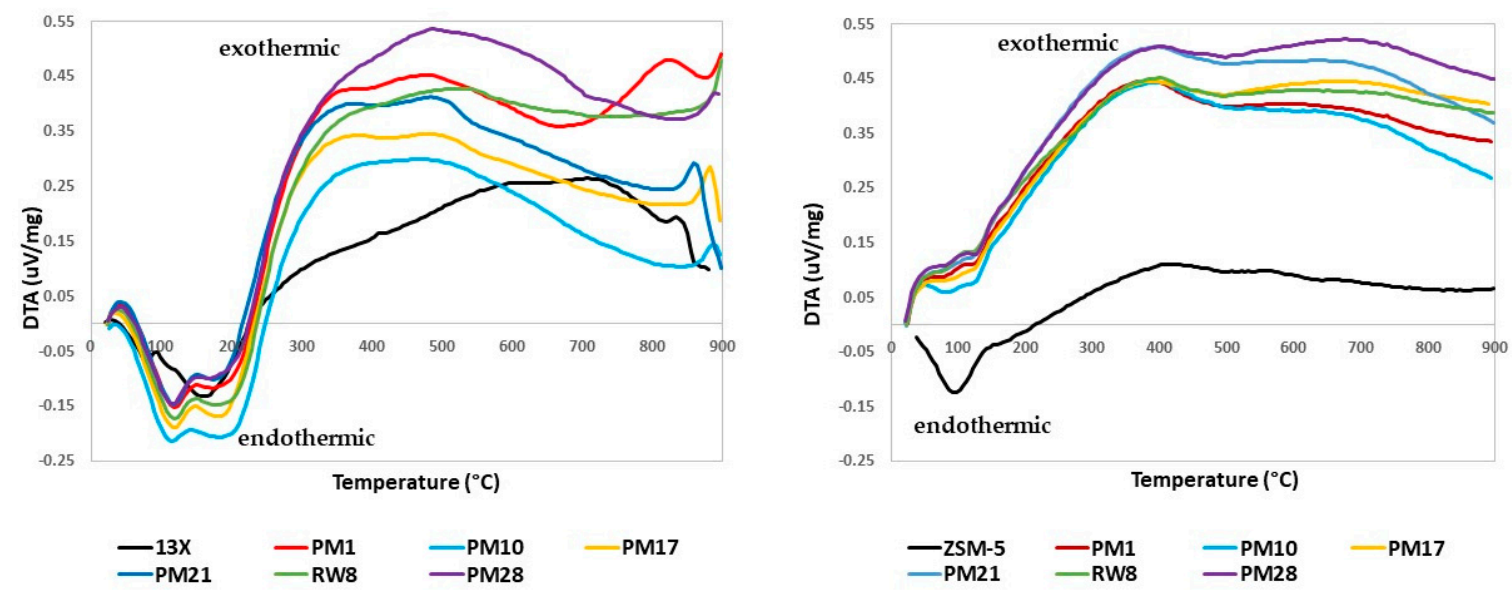

Figure 4. DTA curves of $13 \mathrm{X}$ (left) and ZSM-5 (right) zeolites after adsorption of water from different areas inside the SIN.

For ZSM-5 samples after VOCs adsorption, a comparison of the XRD patterns before and after their permanence in polluted groundwater highlighted relevant changes in the peak intensities in the low $2 \theta$ region but slight modifications of their position. Moreover, the absence of reflection peaks which are forbidden in the monoclinic $P 2_{1} / n$ symmetry revealed that this symmetry was maintained. The unit cell parameters were not remarkably modified (Tables 2 and 3) but a noticeable distortion of the framework was highlighted (Table 5) by the Rietveld crystal structure refinement, clearly indicating a remarkable change in the ellipticity and crystallographic free area of both straight and sinusoidal channels (Table 5). No noticeable variations in the FWHM values as a function of $2 \theta\left(^{\circ}\right)$ were detected and the average grain sizes were $\sim 100 \AA$ before and after VOCs adsorption.

TG analyses showed a first weight loss associated with the elimination of species (water and/or VOCs) weakly bonded to the surface $\left(25-100{ }^{\circ} \mathrm{C}\right.$, weight loss $\left.2.0 \%\right)$, and a second one $\left(100-900{ }^{\circ} \mathrm{C}\right.$, weight loss $\sim 1 \mathrm{wt} \%$ ). In all cases, the last weight loss was related in DTA analyses to two exothermic reactions ascribed to VOCs decomposition (Figure 4). Similar results were already observed in the same ZSM-5 sample after adsorption of BTEX and/or VOCs from water [42-48].

The occurrence of both structural modifications coupled with information on the phase's thermal behavior strongly suggests that both selected zeolites are efficient in the pollutants removal from water.

These results suggested that filters containing the ZSM-5 and 13X, placed in succession, can constitute an efficient adsorption system suitable for the in situ abatement of contaminants in groundwater, such as in the Permeable Reactive Barriers system (PRB). This water remediation technology is often preferred with respect to thermal desorption, groundwater pump-and-treat systems, biodegradation, chemical oxidation, and reduction because of the significant technical and economic advantages, as well as low impacts on the environment [54-66]. With respect to other remediation technologies, the PRB option represents the optimum solution in longevity and cost and does not suffer from back diffusion and rebound issues [67-70]. It has been reported that the PRB system could be installed efficiently with about $60 \%$ cheaper cost than that of the equivalent Pump and Treat system [71-75].

On the basis of this pilot-scale test, a multi-layered PRB could be constructed by combining different reactive materials (13X and ZSM-5). These reactive adsorbent media may successfully remove a wide variety of contaminants, including heavy metals, chlorinated solvents, and aromatic hydrocarbons. 


\section{Conclusions}

The current study was designed to test the efficiency of $13 \mathrm{X}$ and ZSM- 5 adsorbent media in the heavy metals and volatile organic compounds removal of polluted water in the industrial area of Tito Scalo (Basilicata Region in Southern Italy). ZSM-5 zeolite was shown to be suitable for volatile organic compounds (in particular 1,2-dichloroethylene and trichloroethylene), showing high removal efficiencies ( $>87 \%)$. 13X was more selective for in situ abatements of heavy metals with efficiencies up to $100 \%$.

The effective incorporation of VOCs and heavy metal species was confirmed by XRD structure refinements by the Rietveld method (i.e., the variation of both lattice parameters and extraframework content, channels geometry). After heavy metal-exchange on 13X, DTA curves showed different phenomena which can be explained on the basis of the nature and number of metal exchangeable cations hosted in the zeolite micropores (being $\mathrm{Si} / \mathrm{Al}$ ratio constant) and, consequently, to the nominal charge $(Z)$ and radius $(r)$ of the charge-compensating cations. The exothermic peak occurring at high temperature was taken as a reference of zeolites thermal stability and it suggested that the 13X thermal stability increases with increasing ionic radii of the ions in the channel-void system. Consequently, the framework distortion by electrostatic interactions decreases with the increase in ionic radius.

For ZSM- 5 samples after VOCs adsorption, the VOCs decomposition was attested in DTA analyses by two exothermic reactions. In this case, the occurrence of both structural modifications coupled with information on the phase's thermal behavior strongly suggested that ZSM- 5 was efficient in the pollutants removal from water.

These results suggested that filters containing the ZSM-5 and 13X, placed in succession, can constitute an efficient adsorption system suitable for the in situ abatement of contaminants in groundwater, such as in the Permeable Reactive Barriers system (PRB). These reactive adsorbent media can successfully remove a wide variety of contaminants, including heavy metals, chlorinated solvents, and aromatic hydrocarbons.

Author Contributions: Data curation, M.M., L.P.; Methodology, A.A., E.S. and G.V.; Resources, C.B., A.M. and L.P.; Supervision, A.M. and C.B.; Visualization, T.C.; Writing-original draft, A. M.; Writing-review \& editing, A.M. All authors have read and agreed to the published version of the manuscript.

Funding: This research was funded by the 2014-2020 Interreg V-A Italy-Croatia CBC Programme, title of the project: PEPSEA (ID number 10047424).

Acknowledgments: This work was carried out in the framework of the project Protecting the Enclosed Parts of the Sea in Adriatic from pollution, PEPSEA (Project ID: 10047424) within the Interreg V A Italy Croatia Cross-border Cooperation Programme 2014-2020. FAR-2019 funded by the University of Ferrara is also acknowledged for funding. Authors thank UNIRECUPERI S.R.L., Reggio Emilia, Italy for helping and allowing during the polluted groundwater collection. Elisa Rodeghero is acknowledged for laboratory assistance.

Conflicts of Interest: The authors declare no conflict of interest. The funders had no role in the design of the study; in the collection, analyses, or interpretation of data; in the writing of the manuscript, or in the decision to publish the results.

\section{References}

1. Qin, Y.; Li, G.; Gao, Y.; Zhang, L.; Ok, Y.S.; An, T. Persistent free radicals in carbon-based materials on transformation of refractory organic contaminants (ROCs) in water: A critical review. Water Res. 2018, 137, 130-143. [CrossRef] [PubMed]

2. CEC. Regulation (EC) No. 1907/2006 of the European Parliament and of the Council of 18 December 2006 concerning the Registration, Evaluation, Authorisation and Restriction of Chemicals (REACH). 2006. Available online: https://www.desitek.dk/sites/default/files/media/files/DEHN-REACH-Certificate.pdf (accessed on 20 November 2020).

3. Reemtsma, T.; Berger, U.; Arp, H.P.H.; Gallard, H.; Knepper, T.P.; Neumann, M.; Quintana, J.B.; Voogt, P.D. Mind the Gap: Persistent and Mobile Organic Compounds-Water Contaminants That Slip Through. Environ. Sci. Technol. 2016, 50, 10308-10315. [CrossRef] [PubMed] 
4. Darko, G.; Akoto, O.; Oppong, C. Persistent organochlorine pesticide residues in fish, sediments and water from Lake Bosomtwi, Ghana. Chemosphere 2008, 72, 21-24. [CrossRef] [PubMed]

5. dela Cruz, A.L.N.; Cook, R.L.; Dellinger, B.; Lomnicki, S.M.; Donnelly, K.C.; Kelley, M.A.; Cosgriff, D. Assessment of environmentally persistent free radicals in soils and sediments from three Superfund sites. Environ. Sci. Process. Impacts 2014, 16, 44-52. [CrossRef] [PubMed]

6. ISPRA, S.I.N. Siti di Interesse Nazionale-Stato Delle Procedure Per la Bonifica. Dicembre 2018. Available online: http://bit.ly/2MjNp9P (accessed on 20 November 2020).

7. Perego, C.; Bagatin, R.; Tagliabue, M.; Vignola, R. Zeolites and related mesoporous materials for multi-talented environmental solutions. Microporous Mesoporous Mater. 2013, 166, 37-49. [CrossRef]

8. Maretto, M.; Blanchi, F.; Vignola, R.; Canepari, S.; Baric, M.; Iazzoni, R.; Tagliabue, M.; Papini, M.P. Microporous and mesoporous materials for the treatment of wastewater produced by petrochemical activities. J. Clean. Prod. 2014, 77, 22-34. [CrossRef]

9. Colella, C.; Čejka, J.; van Bekkum, H.; Corma, A.; Schueth, F. (Eds.) Introduction to Zeolite Science and Practice, 3rd ed.; Elsevier: Amsterdam, The Netherlands, 2007; pp. 999-1035.

10. Wingenfelder, U.; Hansen, C.; Furrer, G.; Schulin, R. Removal of heavy metals from mine waters by natural zeolites. Environ. Sci. Technol. 2005, 39, 4606-4613. [CrossRef]

11. Sprynskyy, M.; Buszewski, B.; Terzyk, A.P.; Namieśnik, J. Study of the selection mechanism of heavy metal $\left(\mathrm{Pb}^{2+}, \mathrm{Cu}^{2+}, \mathrm{Ni}^{2+}\right.$, and $\left.\mathrm{Cd}^{2+}\right)$ adsorption on clinoptilolite. J. Colloid Interface Sci. 2006, 304, 21-28. [CrossRef]

12. Vignola, R.; Bagatin, R.; Alessandra De Folly, D.; Flego, C.; Nalli, M.; Ghisletti, D.; Millini, R.; Sisto, R. Zeolites in a permeable reactive barrier (PRB): One year of field experience in a refinery groundwater-Part 1: The performances. Chem. Eng. J. 2011, 178, 204-209. [CrossRef]

13. Vignola, R.; Bagatin, R.; Alessandra De Folly, D.; Massara, E.P.; Ghisletti, D.; Millini, R.; Sisto, R. Zeolites in a permeable reactive barrier $(\mathrm{PRB})$ : One-year of field experience in a refinery groundwater. Part 2: Zeolite characterization. Chem. Eng. J. 2011, 178, 210-216. [CrossRef]

14. Zhou, D.; Li, Y.; Zhang, Y.; Zhang, C.; Li, X.; Chen, Z.; Huang, J.; Li, X.; Flores, G.; Kamon, M. Column test-based optimization of the permeable reactive barrier (PRB) technique for remediating groundwater contaminated by landfill leachates. J. Contam. Hydrol. 2014, 168, 1-16. [CrossRef] [PubMed]

15. Northcott, K.A.; Bacus, J.; Taya, N.; Komatsu, Y.; Perera, J.M.; Stevens, G.W. Synthesis and characterization of hydrophobic zeolite for the treatment of hydrocarbon contaminated ground water. J. Hazard. Mater. 2010, 183, 434-440. [CrossRef] [PubMed]

16. Dai, C.; Zhou, Y.; Peng, H.; Huang, S.; Qin, P.; Zhang, J.; Yang, Y.; Luo, L.; Zhang, X. Current progress in remediation of chlorinated volatile organic compounds: A review. J. Ind. Eng. Chem. 2018, 62, 106-119. [CrossRef]

17. Syed, F.H.; Egleston, C.; Datta, R. Tert-Amyl methyl ether (TAME). Thermodynamic analysis of reaction equilibria in the liquid phase. J. Chem. Eng. Data 2000, 45, 319-323. [CrossRef]

18. Colombo, F.; Cori, L.; Dallora, L.; Delogu, P. Equilibrium Constant for the Methyl tert-Butyl Ether Liquid-Phase Synthesis by use of UNIFAC. Ind. Eng. Chem. Fundam. 1983, 22, 219-223. [CrossRef]

19. Safronov, V.V.; Sharanov, K.G.; Rozhnov, A.M.; Alenin, V.J.; Sidorov, S.A. Thermodynamics of Sythesis of tert-Amyl Methyl Ether. Zh. Prikl. Khim.(Leningrad) 1989, 62, 824-828.

20. Rehfinger, A.; Hoffmann, U. Kinetics of Methyl Tertiary Butyl Ether Liquid Phase Synthesis Catalyzed by Ion Exchange Resin-I. Intrinsic Rate Expression in Liquid-Phase Activities. Chem. Eng. Sci. 1990, 45, 1605-1617. [CrossRef]

21. Izquierdo, J.F.; Cunill, F.; Vila, M.; Tejero, J.; Iborra, M. Equilibrium Constants for Methyl tert-Butyl Ether Liquid Phase Synthesis. J. Chem. Eng. Data 1992, 37, 339-343. [CrossRef]

22. Vila, M.; Cunill, F.; Izquierdo, J.F.; Tejero, J.; Iborra, M. Equilibrium Constants for Ethyl tert-Butyl Ether Liquid-Phase Synthesis. Chem. Eng. Commun. 1993, 124, 223-232. [CrossRef]

23. Jensen, K.L.; Datta, R. Ethers from Ethanol. 1. Equilibrium Thermodynamic Analysis of the Liquid-Phase Ethyl tert-Butyl Ether Reaction. Ind. Eng. Chem. Res. 1995, 34, 392-399. [CrossRef]

24. Zhang, T.; Datta, R. Integral Analysis of Methyl tert-Butyl Ether Synthesis Kinetics. Ind. Eng. Chem. Res. 1995, 34, 730-740. [CrossRef]

25. Kitchaiya, P.; Datta, R. Ethers from Ethanol. 2. Reaction Equilibria of Simultaneous tert-Amyl Ethyl Ether Synthesis and Isoamylene Isomerization. Ind. Eng. Chem. Res. 1995, 34, 1092-1101. [CrossRef] 
26. Zhang, T.; Datta, R. Ethers from Ethanol. 3. Equilibrium Conversion and Selectivity Limitations in the Liquid-Phase Synthesis of Two tert-Hexyl Ethyl Ethers. Ind. Eng. Chem. Res. 1995, 34, 2237-2246. [CrossRef]

27. Atik, Z.; Lourddani, K. Densities and Volumetric Properties of Binary and Ternary Mixtures of Diisopropyl Ether, Fluorobenzene, $\alpha, \alpha, \alpha$-Trifluorotoluene, and Ethanol at Temperature $298.15 \mathrm{~K}$ and Pressure $101 \mathrm{kPa}$. J. Solut. Chem. 2006, 35, 1453-1466. [CrossRef]

28. Braschi, I.; Blasioli, S.; Gigli, L.; Gessa, C.E.; Alberti, A.; Martucci, A. Removal of sulfonamide antibiotics from water: Evidence of adsorption into an organophilic zeolite Y by its structural modifications. J. Hazard. Mater. 2010, 178, 218-225. [CrossRef] [PubMed]

29. Guzzinati, R.; Sarti, E.; Catani, M.; Costa, V.; Pagnoni, A.; Martucci, A.; Rodeghero, E.; Capitani, D.; Pietrantonio, M.; Cavazzini APasti, L. Formation of Supramolecular Clusters at the Interface of Zeolite X Following the Adsorption of Rare-Earth Cations and Their Impact on the Macroscopic Properties of the Zeolite. Chem. Phys. Chem. 2018, 19, 2208-2217. [CrossRef]

30. El Brihi, T.; Jaubert, J.N.; Barth, D.; Perrin, L. Determining volatile organic compounds' adsorption isotherms on dealuminated Y zeolite and correlation with different models. J. Chem. Eng. Data 2002, 47, 1553-1557. [CrossRef]

31. Monneyron, P.; Manero, M.H.; Foussard, J.N. Measurement and modeling of single-and multi-component adsorption equilibria of VOC on high-silica zeolites. Environ. Sci. Technol. 2003, 37, 2410-2414. [CrossRef]

32. Benmaamar, Z.; Bengueddach, A. Correlation with different models for adsorption isotherms of $\mathrm{m}$-xylene and toluene on zeolites. J. Appl. Sci. Environ. Sanit. 2007, 2, 43-56.

33. Rodeghero, E.; Chenet, T.; Martucci, A.; Ardit, M.; Sarti, E.; Pasti, L. Selective adsorption of toluene and n-hexane binary mixture from aqueous solution on zeolite ZSM-5: Evaluation of competitive behavior between aliphatic and aromatic compounds. Catal. Today 2020, 345, 157-164. [CrossRef]

34. Martucci, A.; Leardini, L.; Nassi, M.; Sarti, E.; Bagatin, R.; Pasti, L. Removal of emerging organic contaminants from aqueous systems: Adsorption and location of methyl-tertiary-butylether on synthetic ferrierite. Mineral. Mag. 2014, 78, 1161-1175. [CrossRef]

35. Pasti, L.; Rodeghero, E.; Sarti, E.; Bosi, V.; Cavazzini, A.; Bagatin, R.; Martucci, A. Competitive adsorption of VOCs from binary aqueous mixtures on zeolite ZSM-5. RSC Adv. 2016, 6, 54544-54552. [CrossRef]

36. Martucci, A.; Braschi, I.; Bisio, C.; Sarti, E.; Rodeghero, E.; Bagatin, R.; Pasti, L. Influence of water on the retention of methyl tertiary-butyl ether by high silica ZSM-5 and Y zeolites: A multidisciplinary study on the adsorption from liquid and gas phase. RSC Adv. 2015, 5, 86997-87006. [CrossRef]

37. ISPRA. Measurement Procedure for the Determination of Total Hydrocarbons in Waters, Handbooks and Guidelines 23/2015. Available online: https://www.isprambiente.gov.it/en/publications/publicationsof-the-agency-sistem/measurement-procedure-for-the-determination-of-total-hydrocarbons-in-waters (accessed on 20 November 2020).

38. R. US-EPA. Definition and Procedure for the Determination of the Method Detection Limit, 40 CFR Ch. I, 7-1-03 Ed. 2003. Available online: https://www.epa.gov/sites/production/files/2016-12/documents/mdlprocedure_rev2_12-13-2016.pdf (accessed on 20 November 2020).

39. Larson, A.C.; Von Dreele, R.B. General Structure Analysis System (GSAS), Los Alamos National Laboratory Report LAUR 86-748. 1994. Available online: https:/www.ncnr.nist.gov/xtal/software/gsas.html (accessed on 20 November 2020).

40. Toby, B.H. Expgui, a graphical user interface for GSAS. J. Appl. Cryst. 2001, 34, 210-213. [CrossRef]

41. Moran, M.J.; Zogorski, J.S.; Squillace, P.J. Chlorinated Solvents in Groundwater of the United States. Environ. Sci. Technol. 2007, 41, 74-81. [CrossRef] [PubMed]

42. Pasti, L.; Rodeghero, E.; Beltrami, G.; Ardit, M.; Sarti, E.; Chenet, T.; Stevanin, C.; Martucci, A. Insights into Adsorption of Chlorobenzene in High Silica MFI and FAU Zeolites Gained from Chromatographic and Diffractometric Techniques. Minerals 2018, 8, 80. [CrossRef]

43. Pasti, L.; Martucci, A.; Nassi, M.; Cavazzini, A.; Alberti, A.; Bagatin, R. The role of water in DCE adsorption from aqueous solutions onto hydrophobic zeolites. Microporous Mesoporous Mater. 2012, 160, 182-193. [CrossRef]

44. Rodeghero, E.; Martucci, A.; Cruciani, G.; Bagatin, R.; Sarti, E.; Bosi, V.; Pasti, L. Kinetics and dynamic behaviour of toluene desorption from ZSM-5 using in situ high-temperature synchrotron powder X-ray diffraction and chromatographic techniques. Catal. Today 2016, 277, 118-125. [CrossRef] 
45. Rodeghero, E.; Pasti, L.; Sarti, E.; Cruciani, G.; Bagatin, R.; Martucci, A. Temperature-induced desorption of methyl tert-butyl ether confined on ZSM-5: An in situ synchrotron XRD powder diffraction study. Minerals 2017, 7, 34. [CrossRef]

46. Kamiya, N.; Oshiro, T.; Tan, S.; Nishi, K.; Yokomori, Y. Adsorption process of phenol on silicalite-1 and crystal structure of phenol8. 0-silicalite-1 using a single crystal X-ray diffraction method. Microporous Mesoporous Mater. 2013, 169, 168-175. [CrossRef]

47. Martucci, A.; Rodeghero, E.; Pasti, L.; Bosi, V.; Cruciani, G. Adsorption of 1, 2-dichloroethane on ZSM-5 and desorption dynamics by in situ synchrotron powder X-ray diffraction. Microporous Mesoporous Mater. 2015, 215, 175-182. [CrossRef]

48. Martucci, A.; Pasti, L.; Nassi, M.; Alberti, A.; Arletti, R.; Bagatin, R.; Vignola, R.; Sticca, R. Adsorption mechanism of 1, 2-dichloroethane into an organophilic zeolite mordenite: A combined diffractometric and gas chromatographic study. Microporous Mesoporous Mater. 2012, 151, 358-367. [CrossRef]

49. Stumm, W.; Morgan, J.J. Aquatic Chemistry-An Introduction Emphasizing Chemical Equilibria in Natural Waters; Wiley \& Sons: Hoboken, NJ, USA, 1981.

50. Trigueiro, F.E.; Monteiro, D.F.J.; Zotin, F.M.Z.; Sousa-Aguiar, E.F. Thermal stability of Y zeolites containing different rare earth cations. J. Alloy. Compd. 2002, 344, 337-341. [CrossRef]

51. Gal, I.J.; Radovanov, P. Ion-exchange equilibria of synthetic $13 \mathrm{X}$ zeolite with $\mathrm{Ni}^{2+}, \mathrm{Co}^{2+}, \mathrm{Zn}^{2+}$ and $\mathrm{Cd}^{2+}$ ions. J. Chem. Soc. Faraday Trans. Phys. Chem. Condens. Phases 1975, 71, 1671-1677. [CrossRef]

52. Esposito, S.; Ferone, C.; Pansini, M.; Bonaccorsi, L.; Proverbio, E. A comparative study of the thermal transformations of Ba-exchanged zeolites A, X and LSX. J. Eur. Ceram. Soc. 2004, 24, 2689-2697. [CrossRef]

53. Khaleghian-Moghadam, R.; Seyedeyn-Azad, F. A study on the thermal behavior of low silica X-type zeolite ion-exchanged with alkaline earth cations. Microporous Mesoporous Mater. 2009, 120, 285-293. [CrossRef]

54. Babé, A.; Labbé, D.; Monot, F.; Greer, C.W.; Fayolle-Guichard, F. Biodegradability of oxygenates by microflora from MTBE-contaminated sites: New molecular tools. HDB Environ. Chem. 2007, 5, 75-98.

55. Painter, B.D.; Milke, M.W. Comparison of factorial and scenario analysis methods for assessing uncertainty in the design of permeable reactive barriers. Groundwater Monit. Remediat. 2007, 27, 102-110. [CrossRef]

56. Karn, B.; Kuiken, T.; Otto, M. Nanotechnology and in situ remediation: A review of the benefits and potential risks. Environ. Health Perspect. 2009, 117, 1813-1831. [CrossRef]

57. Careghini, A.; Saponaro, S.; Sezenna, E.; Daghio, M.; Franzetti, A.; Gandolfi, I.; Bestetti, G. Lab-scale tests and numerical simulations for in situ treatment of polluted groundwater. J. Hazard. Mater. 2015, 287, 162-170. [CrossRef]

58. Sharma, H.D.; Reddy, K.R. Geoenvironmental Engineering: Site Remediation, Waste Containment, and Emerging Waste Management Technologies; Wiley \& Sons: Hoboken, NJ, USA, 2004.

59. Medvidović, N.V.; Nuić, I.; Ugrina, M.; Trgo, M. Evaluation of natural zeolite as a material for permeable reactive barrier for remediation of zinc-contaminated groundwater based on column study. Water Air Soil Pollut. 2018, 229, 367. [CrossRef]

60. Woinarski, A.Z.; Stevens, G.W.; Snape, I. A natural zeolite permeable reactive barrier to treat heavy-metal contaminated waters in Antarctica: Kinetic and fixed-bed studies. Process. Saf. Environ. Prot. 2006, 84, 109-116. [CrossRef]

61. Vignola, R.; Cova, U.; Fabiani, F.; Grillo, G.; Molinari, M.; Sbardellati, R.; Sisto, R. Remediation of hydrocarbon contaminants in groundwater using specific zeolites in full-scale pump\&treat and demonstrative permeable barrier tests. In Studies in Surface Science and Catalysis; Elsevier: Amsterdam, The Netherlands, 2008; Volume 174, pp. 573-576.

62. Vaezihir, A.; Bayanlou, M.B.; Ahmadnezhad, Z.; Barzegari, G. Remediation of BTEX plume in a continuous flow model using zeolite-PRB. J. Contam. Hydrol. 2020, 230, 103604. [CrossRef] [PubMed]

63. Naidu, R.; Birke, V. Permeable Reactive Barrier: Sustainable Groundwater Remediation; Taylor \& Francis: Oxfordshire, UK, 2015; p. 333.

64. Asante-Duah, K. Management of Contaminated Site Problems; CRC Press: Boca Raton, FL, USA, 2019.

65. Ye, J.; Chen, X.; Chen, C.; Bate, B. Emerging sustainable technologies for remediation of soils and groundwater in a municipal solid waste landfill site-A review. Chemosphere 2019, 227, 681-702. [CrossRef]

66. Chandra, S.; Chauhan, L.K.S.; Murthy, R.C.; Saxena, P.N.; Pande, P.N.; Gupta, S.K. Comparative biomonitoring of leachates from hazardous solid waste of two industries using Allium test. Sci. Total Environ. 2005, 347, 46-52. [CrossRef] 
67. O'Connor, D.; Hou, D.; Ok, Y.S.; Song, Y.; Sarmah, A.K.; Li, X.; Tack, F.M. Sustainable in situ remediation of recalcitrant organic pollutants in groundwater with controlled release materials: A review. J. Control. Release 2018, 283, 200-213. [CrossRef]

68. Johnson, G.R.; Zhang, Z.; Brusseau, M.L. Characterizing and quantifying the impact of immiscible-liquid dissolution and nonlinear, rate-limited sorption/desorption on low-concentration elution tailing. Water Resour. Res. 2003, 39, 39. [CrossRef]

69. Chapman, S.W.; Parker, B.L. Plume persistence due to aquitard back diffusion following dense nonaqueous phase liquid source removal or isolation. Water Resour. Res. 2005, 41, 12. [CrossRef]

70. Krembs, F.J.; Siegrist, R.L.; Crimi, M.L.; Furrer, R.F.; Petri, B.G. ISCO for groundwater remediation: Analysis of field applications and performance. Groundwater Monit. Remediat. 2010, 30, 42-53. [CrossRef]

71. Painter, B.D. Optimisation of Permeable Reactive Barrier Systems for the Remediation of Contaminated Groundwater. Ph.D. Thesis, Lincoln University, Jackson, MO, USA, 2005.

72. Hadley, P.W.; Newell, C.J. Groundwater remediation: The next 30 years. Groundwater 2012, 50, 669-678. [CrossRef]

73. Stroo, H.F.; Unger, M.; Ward, C.H.; Kavanaugh, M.C.; Vogel, C.; Leeson, A.; Marqusee, J.; Smith, B.P. Peer reviewed: Remediating chlorinated solvent source zones. Environ. Sci. Technol. 2003, 37, 224A-230A. [CrossRef] [PubMed]

74. Fan, C.; Gao, Y.; Zhang, Y.; Dong, W.; Lai, M. Remediation of lead and cadmium from simulated groundwater in loess region in northwestern China using permeable reactive barrier filled with environmentally friendly mixed adsorbents. Environ. Sci. Pollut. Res. 2018, 25, 1486-1496. [CrossRef] [PubMed]

75. Faisal, A.A.; Abd Ali, Z.T. Groundwater protection from lead contamination using granular dead anaerobic sludge biosorbent as permeable reactive barrier. Desalin. Water Treat. 2016, 57, 3891-3903. [CrossRef]

Publisher's Note: MDPI stays neutral with regard to jurisdictional claims in published maps and institutional affiliations. 